
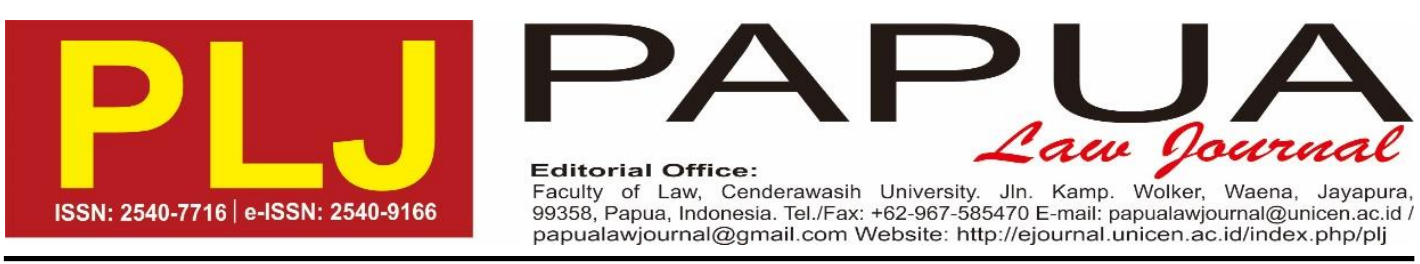

\title{
The Law Enforcement Reform Based on Pancasila Values: A Critical Review
}

\author{
Marthinus Mambaya \\ Faculty of Law, Cenderawasih University \\ Jl. Kamp. Wolker, Waena, Jayapura, 99358, Papua, Indonesia \\ Tel./Fax.: +62-967-585470 E-mail: marthinusmambaya@yahoo.com
}

\begin{abstract}
The influence of colonial law is individual-liberal tempered as well as the globalization is capitalist-liberal tempered became a serious threat to the development of Indonesian law, because it raises the alienation syndrome of State laws from the values of life and upheld in a society that is Pancasila values, therefore the law reform of Indonesia became a necessity to do. This paper focuses on the reform in the field of typical law enforcement in Indonesia, where Pancasila as the ideological basis, in the logic of Stufenbau be the main touchstone which provides ontological, normative and operational frameworks for structuring better law enforcement and typical Indonesian. The principle of Almighty God becomes ontological framework for Indonesian people. Therefore, its existence is inter-related to the Almighty God as the source of value, truth and meaning. Just and civilized humanity is recognized as a ontological base and became the normative framework in order to enforce the law in a fair, civilized and humane, not oppressive character. It is operationalized within the framework of unity, not cause divisions, because all equal in the law as realized by acting wisdom and culminating in social justice for all citizens, social justice in favor of the weak.
\end{abstract}

Keywords: Law Enforcement; Law Reform; Pancasila

\section{INTRODUCTION}

Elaborate the law reform of Indonesia, interesting to observe an argument by Daniel Lev, ${ }^{1}$ which states that "new states inherited a lot thing

1 Daniel S. Lev. (1990). Hukum Kolonial dan Asal-usul Pembentukan Negara Indonesia, Dalam Hukum dan Politik di IndonesiaKesinambungan dan Perubahan, Jakarta: LP3ES, Page. 438 from its predecessor in the colonial era, due to various revolutions that coincided with the total destruction, which is rare in developed countries, cannot wipe out the traces of the past". It is inevitable that Indonesia that was once colonized by the Dutch, until now explicitly or tacit; conscious or not they still inherit the remnants of the colonial 
legal order both structure and its content which individual-liberal tempered. In a view of Satjipto Rahardjo, ${ }^{2}$ has given rise to what is called as "alienation syndrome", a situation where occurs alienation of State's laws from the values of life and upheld in the peoples, so when the law is applied will experience an obstacle.

This nation was not finished cleaning the influence of colonial legal order in establishing a national legal order that is typical of Indonesia, Indonesian legal development is now also facing the challenges of globalization that dominated by the understanding of capitalism and liberalism which is vulnerable to negative impact on the establishment and law enforcement in Indonesia. The issue of globalization is a major problem faced by Indonesia. In this relation, Rahardjo argued that: ${ }^{3}$

"Until now, the pattern of law development is referred to as ordering or arrangement to fulfill law ideals in the constitution. Recently, in the context of the globalization development, need

2 Satipto Rahardjo, (2010), Pembangunan Hukum di Indonesia dalam Konteks Global, as cited in Khudzaifah Dimiyati, Teorisasi Hukum Studi Tentang Perkembangan Pemikiran Hukum di Indonesia 1945-1990, Yogyakarta: Genta Publsihing, Page. 185

${ }^{3}$ Ibid. to conduct a review of the strategy that is seeing "into" it, even if it does not mean release orientation to the law ideals of constitution. The world is also experiencing global economic reconstruction that resulting nation's law in the world experiences internationalization as part of the process".

The influence of colonial law that individual-liberal tempered as well as the impact of globalization that capitalism-liberal tempered became a serious threat to the development of Indonesian law, and became a concerns of legal thinkers in Indonesia, as expressed by Satjipto Rahardjo above. Hence, the law reform of Indonesia is a must, as written by Satjipto Rahardjo as follows: ${ }^{4}$

Development of our national law is the development of national law which is fundamental, because it wants to unpack until the root of old legal order values to be replaced with new ones. Thus, development of national law is not merely in the form of a legal reform, but rather related to the implementation of various concepts, insights, new ideology into the new legal system".

Facing two fundamental problems relating to law reform of Indonesia, as noted above, this paper is

\footnotetext{
${ }^{4}$ Ibid, Page. 184
} 
focused on the reform in the field of law enforcement that is typical Indonesia, namely the law enforcement based on Pancasila values.

\section{METHOD}

This research is categorized into normative-juridical research and oriented to the norms and values that underlie the workings of law in Indonesia. Data sources in the form of primary, secondary and tertiary legal materials are obtained through literature searches both the legislation, expert opinions are documented in the book and the results of research, journals, and Internet media. Overall legal materials gathered are then inventoried and processed and analyzed qualitatively according to the object of study were studied in order to obtain a description of the typical Indonesian law enforcement.

\section{DISCUSSIONS}

The Law Enforcement Reform based on Pancasila Values in the Framework of National Legal System

After Indonesian's independence since 17 August 1945, issue of law reforms of Indonesia has received serious attention nationally. It can be seen with the implementation of national legal seminars that first held since 1963 in Jakarta and continue to the National Law Convention 2008 in Jakarta, which carries the theme of the 1945 Constitution as the constitutional foundation of Grand Design Systems and Political National Law.

The convention has concluded one of important points as well as confirming The 1945 Constitution as the most fundamental law source, the supreme law containing the values, principles and norms that must be obeyed, respected, implemented in decision-making and/or legal policy, either by the government, legislative, and judicial bodies, as well as people in general. Therefore, in the national legal system to be built and its implementation in the form of national legal political, must be maintained and preserved the spirit and the fundamental values embodied in the basic philosophy of Pancasila state contained in the Preamble of the 1945 Constitution and the entire torso as a philosophy foundation and state's constitutional.

The description is to underline that within the framework of Develop- 
ment of National Law/Legal System, the founding father of this nation has laid the solid ideological basis as a base of departure about "what it should be" conducted in a legal reform in Indonesia and about what should it be based on Pancasila as a noble value system of Indonesia nation.

Acceptance of Pancasila values as the noble value system of Indonesia is ultimate and definitive, if placed in the context of law enforcement reform, then all efforts to establish the rule of law in Indonesia, as far as possible leave the system of colonial law and further establish enforcement systems in accordance with Pancasila values, especially the value of Almighty God and a just and civilized humanity. The assertion about the position of Pancasila as the basis of Indonesian law enforcement reform was evident in Act No. 48 of 2009 regarding Judicial Power, Article 1 point 1 which asserts that "Judicial power is the power of the State is free to carry out judiciary to enforce law and justice based on Pancasila and the 1945 Constitution of the Republic of Indonesia, for the implementation of the State Law of the Republic of Indonesia.”
Furthermore, in Article 2

states that: "State justice implements and enforce law and justice based on Pancasila". Since the National Seminar I and National Law Seminars hereinafter, reveal the position of Pancasila within the framework of the national legal systems, among others:

1. National Law Seminar I in 1963, the Principles of Indonesian Law and the National Legal Forms; the principal foundation of Indonesian' law is Pancasila.

2. National Law Seminar III in 1974, the basis of National Law Development is Pancasila, the 1945 Constitution and the Outline of State Policy.

3. National Law Seminar IV in 1979, mentioned reflection of Pancasila values, namely (a) Pancasila containing core values of Indonesian is a basic rule of Indonesian law, guidelines and directions of its development with an open system and touchstone of the appropriateness and legislation; (b) in preparing legislation, the legislators need to pinpoint the values of Pancasila, which underlies the provisions of the constitution. Thus, the legal regulations is the implementation of constitution should not contain things that are contrary to the Pancasila; and (c) reflecting the values of Pancasila in the constitution is the essence of the establishment of the national legal system.

4. National Law Seminar V in 1990, there are important points that law of a nation is "Centrist 
Nation" therefore reasonable if the Indonesian nation teaches "Pancasila Legal System to describe its characteristics, it is necessary to develop the idea of the dispension of justice are better suited to the Pancasila legal system and the development of the Pancasila legal system is based on the moral supremacy.

In addition, various laws and regulations relating to law enforcement, explicitly and clearly stated that law enforcement in Indonesia is law enforcement based on the values of Pancasila, among other stated in:

1. Act No. 48 of 2009 on Judicial Power, article 1 paragraph (1) that the judicial power is the power of the State is independent to organize judicial in order to uphold law and justice based on Pancasila and the 1945 Constitution of the Republic of Indonesia, for the implementation of the Legal State of the Republic of Indonesia, then in Article 2 paragraph (1) states that justice is done "for justice based on God", and Article 2 paragraph (2) that the court implement and enforce law and justice based on Pancasila.

2. Act No. 16 of 2004 on Prosecution, Article 8 paragraph (3) states: "For justice and truth based on Almighty God, the prosecutors to prosecute with confidence based on valid evidence".

3. Act No. 8 of 1981 on the Criminal Procedure Code, Article 197 paragraph (1) stated that, the decision of court that written reads: "For justice based on Almighty God."

\section{Law Enforcement Reform Based on}

\section{Pancasila Values in Indonesian Law}

\section{Expert's View}

Various legal experts in Indonesia was still maintaining that development (Indonesia law reform), should be Pancasila-characterized, which in various terms used, for example Satjipto Rahardjo ${ }^{5}$ use the term "Pancasila law" to accommodate a wide range of characteristics value to be contained by the Indonesian legal system that kinship, fatherly, harmony balance and deliberation. Likewise, Arief B. Sidharta, ${ }^{6}$ called the Pancasila law as the law spirited by Pancasila which based on the principle of harmony and merit, which aims to protect.

A similar opinion argued by Muladi, ${ }^{7}$ and invites all components of the nation to make "Pancasila" as

5 Satjipto Rahardjo. (2003) Sisi-sisi Lain dari Hukum di Indonesia. Jakarta: Penerbit Buku Kompas, Page. 10.

${ }^{6}$ B. Arief Sidharta. (2006). Filsafat Hukum Pancasila, (Paper). Presented on National Seminar regarding Dies Natalis of Pancasila University, Jakarta, Pages 1-5

${ }^{7}$ Muladi. (2006). Pancasila Sebagai Dasar Pengembangan Ilmu Hukum Indonesia. (Paper). Presented on National Seminar regarding Dies Natalis of Pancasila University, Jakarta, Page. 10. 
"Margin of Appreciation" in the development of Indonesian law science. Meanwhile, according to Mahfud MD, the development of law in Indonesia should still make Pancasila as the paradigm, regardless of whether the law on political determinant or otherwise subordinated to politics. ${ }^{8}$

Barda Nawawi Arief, ${ }^{9}$ suggests that if "nation life order" aspired by Indonesia is the order based on Pancasila, the Indonesian Legal Science is the study of the nation life order based on Pancasila. This means establishing a national legal system and essentially build concepts order oriented on Pancasila values /paradigms, namely the paradigm of God (moral-religious), the paradigm of humanity, the paradigm of nationality (union/public interest), the paradigm of populist/democratic, and the paradigm of social justice. Also, can be said briefly that the national legal science (Pancasila Legal Science) is the science

\footnotetext{
${ }^{8}$ Mahfud MD, (2006). Membangun Politik Hukum, Menegakkan Konstitusi. Jakarta: Pustaka LP3ES, Page 17

9 Barda Nawawi Arief, Pembangunan Sistem Hukum Nasional Indonesia, Padang, 16 Mei 2009, pg. 8, accessed from: http://bardanawawi.worldpress.com/2009/12/2 4/38/
}

oriented on three pillars/value of Pancasila balance, namely: "God" values-oriented (moral religious), oriented to the values of "humanity"; and to the values of "community" (nationalistic, democratic, social justice).

According to Bismar Siregar that the laws in our country are based on Pancasila, ${ }^{10}$ and in the first mention the spirit of Almighty God that became the basis of the State and as the basis of law and justice. Its consequence that law must be obeyed by any person as Indonesian citizen and at the same time Indonesia is a law that the spirit of Almighty God. This view is in line with proposed by Hazarin, ${ }^{11}$ law and law science are applicable and enforced in this country should be one soul and the breath of Almighty God.

The essence of law based on Pancasila and spirited by Almighty

\footnotetext{
${ }^{10}$ Talking about the law based on Pancasila, interesting to note the opinion of W. Poespoprodjo (2007) that states: When pursued to the ends of thinking, then the national law should be the Pancasila law. This means that national laws should as far as possible completing Pancasila" see Antonius Sudirman, Hati Nurani Hakim dan Putusannya Suatu Pendekatan dari Perspektif Ilmu Hukum Perilaku (Behavioral Jurisprudence) Kasus Hakim Bismar Siregar. Bandung: Citra Aditya Bakti, Page. 139

11 Bismar Siregar.(1989). Bunga Rampai Karangan Terbesar Bismar Siregar.Jakarta: Rajawali, Page. 94
} 
God is the law that reflects the nature of Merciful God, not legal oppressorscharacterized. However, if the law is not in accordance with the nature of God, not the law and the law must be out of circulation. The concrete form of any product that is statutory must correspond to the sense of justice in society or in accordance with the reality of a society; not otherwise ignore the demands for social justice and protecting the interests of certain groups. Law according to the spirit of Almighty God, not only in terms of legal materials, but also concerns the application and implementation of the law. ${ }^{12}$ For example, in the case investigators investigative or a judge in a criminal case. Investigators and judges should be able to demonstrate the love, affection, and unfortunately the suspect/defendant.

From various the National Law Seminar and Indonesian law expert opinion, as stated above, it seems clear that the development of the National Legal System including law enforcement and justice in Indonesia is based

12 Harifin Tumpa. (2015). Penerapan Konsep Rechtsvinding dan Rechtsschepping oleh Hakim dalam Memutus Suatu Perkara.Hasanuddin Law Review, 1(2), 126138. http://dx.doi.org/10.20956/halrev.v1n2.90 and relies on the values of Pancasila. According to Poespowardojo, ${ }^{13}$ the values of Pancasila is the nation's agreement as the basis for the State, ${ }^{14}$ the nation's philosophy of life, the moral ideals of the nation and State ideology. ${ }^{15}$

\section{Pancasila as Ideological Basis of Law}

\section{Enforcement}

Speaking law enforcement reform, it cannot be separated from the law enforcement system that exist

13 M. Soerjanto Poespowardojo, Menangkap Aspirasi Pancasila Dalam Rangka Pengembangan Ilmu Hukum di Indonesia (Suatu Penjelajahan Epistemologis). A paper presented at the National Seminar on Pancasila Values as Fundamental Value for the Development of Indonesia Law Science, December 7, 2006, Jakarta, Page. 4

14 Pancasila as the basis of state is concluded in the preamble of the 1945 Constitution paragraph IV," then drafted this independence of Indonesian in the constitution of Indonesia, which is formed in an arrangement of the Republic of Indonesia which people sovereignty, based on the Almighty God, just and civilized humanity, the unity of Indonesia, democracy led by the wisdom of deliberations representatives as well as by fostering a social justice for all Indonesian people".

${ }^{15}$ As the foundation of the State, Pancasila is a spritual principle which in the state science known as the basic philosophy of the State (Philosofische gronslag), is a source of value and norms in every aspect of the implementation, while as a national ideology, Pancasila in essence is not only a result of contemplation or thought a person or group of people, but Pancasila raised from the values of customs, cultural and religious contained in the view of the Indonesian people as materials cause of Pancasila (material origin). See Kaelan. (2010). Pendidikan Pancasila, Yogyakarta: Pages. 110-114. 
today, to be brought to an ideal system of law enforcement, as expressly stated in Act No. 48 of 2009 on Judicial Power, Article 1 paragraph 1 that "Judicial power is the power of the State is independent to carry out judiciary to enforce law and justice based on Pancasila and the 1945 Constitution of the Republic of Indonesia, for the implementation of the law State of the Republic of Indonesia", and Article 2 paragraph (2) that: "State justice implement and enforce law and justice based on Pancasila".

Read the Act (Act No. 48 of 2009), soon be apprehended that Indonesian law enforcement is supposed to have the ideological basis of Pancasila as an ideology contains the most central and essential values which should be the basis for the assessment and improvement of all aspects of national life and the state of Indonesia, including in order to law reform, especially law enforcement in Indonesia, as stated by Bernard L. Tanya, ${ }^{16}$ that in an effort to build Indonesian law, the ideological basis is

${ }^{16}$ Bernard L. Tanya. (2011). Politik Hukum Agenda Kepentingan Bersama. Yogyakarta: Genta Bublishing, Page. 15
Pancasila, which in the framework of the legal political has provided a framework of ontological, normative and operational are very solid for ordering life better nation.

Make Pancasila as the ideological basis of law enforcement reform in Indonesia, because of Pancasila has values of God, humanity, unity, democracy and social justice, and believed to be the essential and fundamental values deemed noble enough (and therefore demand obedience) to serve as the guiding principle, norms of criticism once the source of motivation for any law enforcement action. Various references can be used as a justification for this, as described below.

Value of God, meaning everything sourced from Almighty God and will return to Almighty God. In the philosophy of existentialism, it is understood that existence before essence. Starting from such thought, the essence of all human beings are equal in Almighty God, the difference between one human to another is the existence in their actions. ${ }^{17}$ When

\footnotetext{
${ }^{17}$ Research Team of Law Faculty, "Nilainilai Pancasila Sebagai Nilai Dasar Pengembangan Ilmu Hukum". A paper
} 
person doing good, truly, not violate the rights of others, he was building his existence, practice God value vertically as accountability essence to Almighty God and horizontally to the nation, the community in making man a friend to him/others (homo homini sosius).

Relevant to point out in this context, the teaching of Hans Kelsen about Grundnorm, who proposed 4 (four) indicators, namely:

1. Grundnorm is abstract something, assumed, not written, and applicability universal.

2. It did not gesetzt (determined), but vorausgesetzt (assumed) there by human reason.

3. It did not belong to the order of positive law it is outside, but as basis for the enforceability of the highest order of positive laws. It is meta juristic.

4. Should obey or behave as specified by the constitution. ${ }^{18}$

Using a thought system of Hans Kelsen (Grundnorm Theory), ${ }^{19}$ that a rule should not be contrary to the rules

presented at the National Seminar on Pancasila Values as Fundamental Value for the Development of Indonesia Law Science, In Collaboration with UGM - Pancasila University. December 7, 2006, Jakarta, Page 5

18 Jazim Hamidi. (2006). Kedudukan Hukum Naskah Proklamasi 17 Agustus 1945 Dalam Sistem Ketatanegaraan Republik Indonesia. Jurnal Konstitusi, Volume 3 No. 1, Februari 2006, Page 163

19 Bernard L. Tanya, dkk. Teori Hukum Strategi Tertib Manusia Lintas Ruang dan Generasi, CV. Kita, Surabaya, 2006, Pages 104-106 that are on a higher level, culminating in Grundnorm. A rule to be valid as a law, is not enough by legality, but mainly is compliance with the higher norms, where Grundnorm be the last measure. Similarly, in the field of law enforcement, checking the validity of the law enforcer's actions is not enough just based on the norm, but it requires checking through stufenbau logic, and Pancasila as Grundnorm be the main touchstone.

As Grundnorm, Pancasila is an ideological base that not only provides an ontological and normative framework, but also gave a very solid operational framework for ordering better lives of people. ${ }^{20}$ Pancasila with Almighty God value gives ontological framework for Indonesian people, that human existence is inter-related to the Almighty God who is believed to be the source of value, the source of truth and meaning. Values, truth and meaning that comes from the Almighty God leads human to live civilized, fair and humane as stated in the second principle of Pancasila as well as a normative framework, as well as the

\footnotetext{
${ }^{20}$ Ibid., Page 15.
} 
three principles of Pancasila which became operational framework.

Pancasila as the fundamental or basic rules of positive law, including its enforcement (staatsfundamental-norm), which represents the ideals of law, frame of mind, the source of values and direction of change in Indonesian law. At this point Pancasila used as a paradigm change in the law, which by Muladi, ${ }^{21}$ for example, refer to Pancasila as 'the margin of appreciation', the benchmark of ethics and morals, honor and dignity of nation, as well as the norms of criticism (evaluation rule) in facing the challenges related with law enforcement. Thus, Pancasila become a basic norm which covers all the legal processes both in the law-making process and implementation.

By making Pancasila as the ideological basis of law enforcement, then the normative values of Pancasila be a transcendental precondition (foundation and benchmarks) underlying every action of law enforcement officers as well as the constitutive, directing the goals to be achieved from

21 Muladi. Menggali Kembali Pancasila Sebagai Dasar Pengembangan Ilmu Hukum Indonesia, Jurnal Hukum Progresif, 2005 the law enforcement justice based on Pancasila.

First principle of Pancasila, presents ontological framework of Indonesian people, that human existence is inter-related to the Almighty God that is believed to be the source of value, truth and meaning. According Notonagoro, ${ }^{22}$ the principle of Almighty God in the philosophy of Pancasila is a value even core values for nationhood and statehood. God is the origin of all things, the existence of God is absolute, perfect and power, has not changed, not limited and as a regulator of the natural order. In restructuring the lawless life, the recognition of God as the primary cause, the source of values, truth and meaning, not only to be recognized as formulated various regulations related to law enforcement, but demand obedience of man to carry it out.

According to Kaelan, the values contained in the principle of Almighty God are that the State is established as a manifestation of human interest as creature of Almighty God. Therefore, all matters relating to the implementation and operation of the State

22 Notonagoro. (1975). Pancasila Ilmiah Populer. Jakarta: Pantjuran Tujuh, Page 78 
even State moral, State administrator moral, the State government, the laws and regulations of State, freedoms and rights of citizens must be imbued with the values of Almighty God. ${ }^{23}$

Law according to the Spirit of Almighty God, not only in terms of legal materials, but also concerns the application and implementation of the law. For example, in the case of investigator conduct an investigation, prosecutors in prosecuting and judges in adjudicating a case (criminal). Investigators, prosecutors and the judge ought to be able to show love, compassion, and unfortunately the suspect/defendant, with emphasis on fairness, honest (fair) in performing law enforcement duties to ensure the fulfillment of the rights of suspects/ defendant according to law.

Value of God, meaning everything sourced from Almighty God and will return to Almighty God. In the philosophy of existentialism, it is understood that existence before essence. Starting from such thought, it is the essence of all human beings are

23 Kaelan and Achmad Zubaidi. (2007). Pendidikan Kewarganegaraan Untuk Perguruan Tinggi Berdasar SK Dirjen Dikti No. 43/DIKTI/KEP/2006/ Yogyakarta: Paradigma, pg. 32, See also: Kaelan, Pendidikan Pancasila..., Op. Cit. Page. 79. equal in Almighty God, the difference between one human to another is the existence in the form of actions. ${ }^{24}$ When doing good, truly, does not violate the rights of others, he was building his existence, practice value Godhead vertically as accountability essence to Almighty God and horizontally to the nation, the community in making man a friend to him/others (homo homini sosius).

The second principle is just and civilized humanity. Therefore, the first principle "Almighty God" is recognized as a basic ontological, the consequences for people who acknowledge God as the source of values, truth and meaning in life arbitrate required for equitable, civilized and humane, then the second principle "just and civilized humanity" became the normative framework. Pancasila philosophy is viewing the law as a moral order, so it takes the moral order as a guide to life in enforcing the law, which is just,

\footnotetext{
${ }^{24}$ Research Team of Law Faculty, "Nilainilai Pancasila Sebagai Nilai Dasar Pengembangan Ilmu Hukum". A paper presented at the National Seminar on Pancasila Values as Fundamental Value for the Development of Indonesia Law Science, In Collaboration with UGM - Pancasila University. December 7, 2006, Jakarta, Page 5
} 
civilized and humane. This is very different from the Ionian ${ }^{25}$ philosophy that views law as an order of strength, "appeared" or "disappeared", the law is survive. ${ }^{26}$

Ways to just, civilized and humane law is a means to enforce the law as it was conceived in Progressive Legal Theory by Satjipto Rahardjo, ${ }^{27}$ which the law is intended to protect the people towards the ideal of law, reject the status quo and do not want to make the law as technology no conscience but a moral institution, which aims leads man to life a just, prosperous and happy. The law is for man, not vice versa.

The third principle is the unity of Indonesia, became a national operating framework for law enforcement in Indonesia. Operating of law enforcement, should not cause divisions. Therefore, there is no place for discriminatory treatment in law enforcement throughout the territory of

${ }^{25}$ In view of Ionia philosophy, law is order governed by strength logic. There is no different between natural and human rules, both regarded as part of natural logic that is strength logic.

26 Bernard L. Tanya et al., (2006) Teori Hukum Strategi Tertib Manusia Lintas Ruang dan Generasi. Surabaya: CV. Kita, Page. 16

27 Satjipto Rahardjo. (2009). Hukum Progresif, Sebuah Sintesa Hukum Indonesia, Genta Publishing, Pages 1-6 the Republic of Indonesia. The 1945 Constitution Article 27 paragraph (1) is a derivation of the value of unity in the third principle of Pancasila, and operationalized in law enforcement through the principle of "equality in the law" as a fundamental principle of the Criminal Procedure Code. It is not justified the preferential treatment for groups, groups based on ethnicity, religion. All have the right to be treated equally in the law and all have the same obligations under the law. Thus, every nation is entangled with the law, felt safe being treated by the principle of equality in the law.

The fourth principle is populist led by the wisdom of deliberations/ representatives are the operational framework of the state. In the field of law enforcement, the State apparatus is required to act full of wisdom and discretion. Therefore, power abuse in law enforcement, not only contrary to the humanitarian principles that damage the rights of the suspect/ defendant to be treated with dignity, but it is the duty of law enforcement officers to act full of wisdom and discretion.

The fifth principle is social justice for all Indonesian people, as 
operational framework of the rule of law in social life. To be realized in law enforcement by the fifth principle is that law enforcement culminating in social justice for all people, justice is mutual cooperation. In law enforcement, rights and obligations are like two sides of a coin. Likewise, with justice, there is a demand for justice that is meritocratic, a justice based on merit or achievement, justice based on the right.

A suspect/defendant has right to demand legal lawyer paid to struggle his right in front of the law, but it does not mean that a suspect/defendant who cannot afford economically to pay the lawyer, his rights in front of the law is neglected. Hence, if so, then social justice for all peoples just a hope that cannot be felt. Law enforcement requires affirmative action, favor the weak that are unable to defend their rights, namely social justice, justice in favor of the weak.

\section{CONCLUSION}

Based on earlier notes about the values of Pancasila as the basis of law enforcement reform in Indonesia, it is clearly efforts to build a legal system, including the law enforcement reform that is typical Indonesia, which has Pancasila ideology base. Choosing Pancasila as the ideological basis for law enforcement reform due to the values of Pancasila is believed to be the essential values that can be the basis of departure on what should be done in realizing the rule of law, justice based on God, humanity and social justice. Those values become typical of Indonesia because generally it is not contained nature of individualism, liberalism, and capitalism that animates modern law (west).

By building a legal system (law enforcement) based on the values of Pancasila, it is believed that efforts to erode the remnants of individual-liberal tempered colonial legal order as well as to protect the impact of globalization on the development of Indonesian law that carries capitalism and liberalism values can be good realized.

\section{BIBLIOGRAPHY}

Antonius Sudirman, Hati Nurani Hakim dan Putusannya Suatu Pendekatan dari Perspektif Ilmu Hukum Perilaku (Behavioral Jurisprudence) Kasus Hakim Bismar Siregar. Bandung: Citra Aditya Bakti.

B. Arief Sidharta. (2006). Filsafat Hukum Pancasila, (Paper). Presented on National Seminar 
regarding Dies Natalis of Pancasila University, Jakarta.

Bernard L. Tanya et al., 2006. Teori Hukum Strategi Tertib Manusia Lintas Ruang dan Generasi, CV. Kita, Surabaya.

Bernard L. Tanya. (2011). Politik Hukum Agenda Kepentingan Bersama. Yogyakarta: Genta Publishing.

Bismar Siregar. (1989). Bunga Rampai Karangan Terbesar Bismar Siregar. Jakarta: Rajawali.

Daniel S. Lev. (1990). Hukum Kolonial dan Asal-usul Pembentukan Negara Indonesia, Dalam Hukum dan Politik di IndonesiaKesinambungan dan Perubahan, Jakarta: LP3ES.

Harifin Tumpa. (2015). Penerapan Konsep Rechtsvinding dan Rechtsschepping oleh Hakim dalam Memutus Suatu Perkara. Hasanuddin Law Review, 1(2), 126-138. doi: http://dx.doi.org/ 10.20956/halrev.v1n2.90

Jazim Hamidi. (2006). Kedudukan Hukum Naskah Proklamasi 17 Agustus 1945 Dalam Sistem Ketatanegaraan Republik Indonesia. Jurnal Konstitusi, Volume 3 No. 1.

Kaelan and Achmad Zubaidi. (2007). Pendidikan Kewarganegaraan Untuk Perguruan Tinggi Berdasar SK Dirjen Dikti No. 43/DIKTI/KEP/2006/. Yogyakarta: Paradigma.

M. Soerjanto Poespowardojo, Menangkap Aspirasi Pancasila Dalam
Rangka Pengembangan Ilmu Hukum di Indonesia (Suatu Penjelajahan Epistemologis). Paper presented at the National Seminar on Pancasila Values as Fundamental Value for the Development of Indonesia Law Science, December 7, 2006, Jakarta.

Mahfud MD, (2006). Membangun Politik Hukum, Menegakkan Konstitusi. Jakarta: Pustaka LP3ES.

Muladi. (2005). Menggali Kembali Pancasila Sebagai Dasar Pengembangan Ilmu Hukum Indonesia, Jurnal Hukum Progresif.

- (2006). Pancasila Sebagai Dasar Pengembangan Ilmu Hukum Indonesia. (Paper). Presented on National Seminar regarding Dies Natalis of Pancasila University, Jakarta.

Notonagoro. (1975). Pancasila Ilmiah Populer. Jakarta: Pantjuran Tujuh.

Satjipto Rahardjo. (2003) Sisi-sisi Lain dari Hukum di Indonesia. Jakarta: Penerbit Buku Kompas. . (2009). Hukum Progresif, Sebuah Sintesa Hukum Indonesia, Genta Publishing. . (2010), Pembangunan Hukum di Indonesia dalam Konteks Global on Khudzaifah Dimiyati, Teorisasi Hukum Studi Tentang Perkembangan Pemikiran Hukum di Indonesia 1945-1990, Yogyakarta: Genta Publsihing. 